\title{
INVESTIGAÇÕES PARASITÁRIAS, BACTERIANAS E FÚNGICAS EM GRUPOS EM LIBERDADE, SEMI- LIBERDADE E CATIVEIRO DA ESPÉCIE Amazona brasiliensis - PAPAGAIO-DE-CARA-ROXA
}

\section{MARIA DE LOURDES CAVALHEIRO}

Universidade Federal do Paraná. Mestranda do Curso de Engenharia Florestal - Área de Concentração Conservação da Natureza - Laboratório de Manejo de Fauna.

O papagaio-de-cara-roxa é uma espécie endêmica de partes da região litorânea em uma estreita faixa que compreende o norte de Estado de Santa Catarina, Paraná e sul do Estado de São Paulo. A espécie está listada no Threatened Birds of the Americas - The ICBP/IUCN Red Data Book (COLLAR, 1992), além de ser umas das 27 espécies de papagaio configurada no CITES (Convention on International Trade in Endangered Species of Wildlife Fauna and Flora). O estudo de aspectos fisiológicos e epizootiológicos contribui para as futuras práticas de manejo que objetivam a proteção, manutenção e auto-sustentação das populações. O presente trabalho traz resultados da investigação parasitária, bacteriana e fúngica obtidos por 2 anos em indivíduos da espécie Amazona brasiliensis. Fezes e swabs cloacais, de coanas e de pele foram utilizados para exames, sendo que o material colhido de indivíduos pertencentes à população livre foi extraído de filhotes durante períodos reprodutivos da espécie. Exames parasitológicos das fezes foram realizados pelo método de flotação em líquido de Sheather. Para os exames bacterianos utilizaram-se placas com meio de cultura ágar McConkey, ágar SS e coloração de Gram. A identificação final de bacilos Gram negativos foi feita através da utilização de uma bateria para pesquisa de enterobactérias (laboratório Newprov). Para os exames fúngicos foi feito o cultivo em ágar Sabouraud. O único endoparasita intestinal encontrado na população livre foi Eimeria spp. Os indivíduos dos grupos em cativeiro e em semi-liberdade apresentaram Eimeria spp, Ascaridia spp, Ascaris spp e Trichostrongylus spp. Na identificação final de enterobactérias, os indivíduos de vida livre, cativeiro e de semi-liberdade apresentaram crescimento predominante de Escherichia coli e Proteus mirabilis em todas as culturas. No meio ágar SS, houve maior crescimento de Shigella spp entre indivíduos do grupo em liberdade e em cativeiro. Já indivíduos do grupo em semi-liberdade tiveram maior crescimento de Salmonella spp. A pesquisa fúngica apontou crescimentos semelhantes de fungos unicelulares filamentosos com gemulações e morfologia sugestiva do gênero Candida e de fungos com hifas septadas, com vesículas onde esterígmas começaram a crescer. Esta morfologia é sugestiva do gênero Aspergillus. O achado exclusivo de coccídeos do gênero Eimeria em indivíduos clinicamente saudáveis de vida livre, significa que esses indivíduos são prováveis carreadores desse endoparasita. O diagnóstico de coccidiose porém, só é dado com o achado de vários oocistos nas fezes concomitante aos sinais clínicos. O mesmo raciocínio deve ser estendido aos demais achados que são uma parte das investigações realizadas com a espécie. Esses resultados estão contribuindo para o conhecimento de importantes fatores epizootiológicos e elaborando um plano de ação onde metas são priorizadas para que o manejo veterinário, em cativeiro e em vida livre, contribua para a conservação da espécie. 